\title{
Protected Designation of Origin as driver of change in goat production systems: Beyond added value
}

\section{La Denominación de Origen protegida como impulsor de la transformación de los sistemas de producción caprina: más allá del valor añadido}

Luis Alberto Bermejo ${ }^{1}$, Débora Andrea Evangelista Façanha ${ }^{2}$, Nieves Beneda Guerra ${ }^{1}$, Juan José Viera ${ }^{1}$

Originales: Recepción: 08/06/2020 - Aceptación: 17/02/2021

\begin{abstract}
Protected Designation of Origin (PDO) is one of the EU tools for rural development. Most of the literature on this subject is focused on premium prices and consumers' willingness to pay for local products, since PDO and other labels aim to provide premium incomes for farmers. Our hypothesis states that PDO may also drive unexpected changes in farming styles, not only related to processing or market strategies, but also related to local resources usage, establishing different approaches to agriculture and food production. The PDO of Queso Palmero (La Palma cheese) was analyzed as a dual label system case (brand-certification and common label), thus enabling comparisons between farmers involved in a PDO scheme with farmers who work outside the systems. It was concluded that, for price formation, private brands are more important than common label certification, but complementary to each other, since PDO reinforces farmers' efforts to improve quality. Beyond premium price, PDO also drives a radical change in farm structures, since it reconnects products to local resources (grazing $v s$ intensification) and redesigns relationships with markets (shortening and diversifying chains and widening product offer). This change is characterized by implementation of new farming strategies in the context of a PDO structure that coexists with classical farming strategies closer to intensification, not only in terms of productivity, but also in terms of decoupling from local resources and productive and market specialization. Therefore, PDO is a powerful tool for rural development in a wider sense (resilience, empowerment, local capacity and network formation, among others) far beyond its narrow remit of promoting economic growth (local or regional). Therefore, coupling with local resources and strengthening local networks and relationships as sources of resilience, knowledge and capabilities improvement, have to be included in performance assessment of GIs (Geographical indications) in order to broaden the appraisal of their role in regional development.
\end{abstract}

\section{Keywords}

Quality label • farming style $\bullet$ rural development $\bullet$ farmers' perception $\bullet$ innovation

1 Universidad de La Laguna. Departamento de Ingeniería Agraria, Náutica, Civil y Marítima. Escuela Politécnica Superior de Ingeniería. Avenida Ángel Guimerá Jorge, s/n. 38200 San Cristóbal de La Laguna (Tenerife). España. lasensio@ull.edu.es

2 Universidade Federal Rural do Semi-Arido. Laboratory of Adaptive Physiology and Genetic Resources. Department of Animal Science. Rua Francisco Mota Bairro. 572 Pres. Costa e Silva. Mossoró - RN. 59625-900, Brasil. 


\section{RESUMEN}

Las denominaciones de origen protegida (DOP) es una de las herramientas de la Unión Europea para el desarrollo rural. La mayor parte de la literatura en relación con las DOP, está centrada en el valor añadido y en la disposición a pagar por los consumidores por productos locales, ya que las DOPs y otras etiquetas tienen como objetivo, entre otras cosas, incrementar los ingresos de los productores. Nuestra hipótesis es que las DOPs y otras etiquetas de calidad impulsan cambios inesperados en los sistemas y estilos de agricultura, no solo relacionados con las estrategias de comercialización o los procesos industriales sino también con el uso de los recursos locales y el establecimiento de diferentes estrategias de producción agraria y alimentaria. En este trabajo analizamos la DOP Queso Palmero (Islas Canarias, España) como un estudio de un sistema dual de etiquetado (marca individual - etiqueta común) ya que nos permite comparar productores implicados en el esquema de la DOP con ganaderos, que cumpliendo los requerimientos, no forman parte de la DOP. Concluimos que las marcas privadas individuales son más importantes que la etiqueta común (DOP) en la formación del precio, pero ambas son complementarias, ya que la DOP impulsa el esfuerzo de los ganaderos por mejorar la calidad. Más allá del incremento de precio, la DOP impulsa cambios radicales en los sistemas de producción al reconectar las explotaciones con los recursos locales (pastoreo frente la tendencia a la intensificación productiva) y reconfigura las relaciones con el mercado (acortando y diversificando los canales de comercialización y ampliando la oferta de productos). Estas nuevas estrategias desarrolladas en el contexto de la DOP, coexisten con estrategias clásicas más cercanas a la intensificación, no solo en términos de la importancia de la productividad en la toma de decisiones sino en términos de desacoplamiento respecto de los recursos locales y de especialización productiva y en los canales de comercialización. Por tanto, las DOPs son una potente herramienta de desarrollo rural en un sentido amplio (resiliencia, empoderamiento, formación de redes y capacidad locales entre otros), más allá del objetivo de crecimiento económico (local y regional). El reacoplamiento con los recursos locales y el fortalecimiento de las redes y relaciones locales como fuente de resiliencia, así como la mejora del conocimiento y las capacidades, deben ser incluidos en la evaluación de las indicaciones geográficas y otras etiquetas de calidad, para ampliar el análisis de su rol en el desarrollo regional.

\section{Palabras clave}

Etiquetas de calidad • estilos de agricultura • desarrollo rural • percepción de los productores $\bullet$ innovación

\section{INTRODUCTION}

Protection of local food products (Geographical indications) is an EU tool for rural development included as a measure within the second CAP (Common Agricultural Policy) pillar, and a priority related to improving agriculture competitiveness by increasing farmers' incomes through adding value to products (46). Several studies show that certain groups of consumers are willing to pay higher prices for local products, since they are associated with benefits such as health, freshness, reduced carbon footprint, local culture, different tastes and traditions $(4,35,37)$. These local products respond to postindustrial society's demands, as these new attributes play an important role in nutrition (5), price and income (48) choices. Therefore, late modern (postmodern) consumers are willing to pay for these (new and rediscovered) attributes of food products. In this context, EU labeling protects these products against fraudulent marketing, providing information to ensure higher prices of labeled products, thus improving farmers' income (46) as driver of rural development. Ten percent of over 3,300 European geographical indications are in Spain, where labels have increased more than 5\% between 2012 and 2017 (32).

However, there are two important factors related to the implementation of quality certification systems. On the one hand, some authors have found that labeling systems entail higher costs and lower efficiency that is not always offset by higher incomes from added value $(7,10,27)$. Therefore, the viability for these farms in comparison with more industrialized ones can be undermined. In addition, premium prices are often low in products with 
high processing levels, such as cheeses, wines, or olive oil (13). This is due to the longer crafting process used to imbue these products with distinct and specific traits in order to differentiate them, even from official protection labels. Moreover, for some products, brands are preferred to protected labels by consumers, as they also guarantee quality and origin (6). Indeed, in many cases, personal relationships with farmers, proximity (5) and contribution to local economy (35) play a more important role in purchasing behavior than certification. Finally, depending on the market structure and organization, premium pricing does not always make an impact on rural development (8). However, quality labels can play a prominent role in the protection of ecosystem services, such as cultural heritage $(19,28)$ and local genetic animal resources (49). In this context, systems and institutions for local product valorization can facilitate local breed protection and rural development $(21,22)$ since many Geographical Indication (GI) regulations require farms to produce on the basis of local breeds. Therefore, the results of PDO initiatives are conditioned by local socioeconomic conditions (9), both in terms of not reaching expected objectives as well as in producing unexpected and indirect effects such as changes in land use $(20,40)$.

Literature on premium prices and the effect of GIs on rural development at regional scale is extensive, particularly as the main aims of European quality labels are related to these issues $(8,9,47)$. However, the role of GIs as unexpected drivers of farm transformation has been less addressed (20), not only from the point of view of productive structure changes, but also from the point of view of farmers' characteristics (value, goals and emotions) and decision-making (22). Benefits of GIs beyond economic dimensions are not sufficiently understood (31) and not frequently included in decision-making and assessment tools (18).

This research attempts to answer some key questions. First, do GIs provide premium prices for goats' cheese? Could there be other reasons for farmers and the public administration's involvement in GIs besides premium price? Second, to what extent do GIs drive changes in production strategies and farming styles (different strategies to obtain similar income levels and ensure system reproduction (38))? Finally, do GIs lead to innovation in agriculture beyond the required rules?

A PDO for goats' cheese, Queso Palmero, was used as a case study for three reasons: 1) As a processed product, its premium price is probably low (PDO price similar to non-PDO prices); 2) Brands are always present among PDO cheeses; 3) It involves a supply chain strategy, since there is a focus on managing production levels, improving product quality and implementing effective marketing (47). Therefore, these circumstances highlight motivations other than the expected advantages (46) for farmers' involvement in PDO structures. PDO Queso Palmero is managed by a regulating council under the Canary Island Regional Government's authority. The regulating council is composed of technical experts, farmers and cheese makers.

From an empirical perspective, this case allows us to compare the two types of farmers (PDO and non-PDO farmers) in a shared socio-economic and cultural context and in a limited and isolated geographical area. Therefore, study factors have been effectively isolated in the statistical models. Hence, it can be assumed farmers have similar production costs (ultraperipheral islands are closed systems, input market options are reduced), and they all know and are aware of the market costs of different channels. Therefore, information is symmetrically available, and farmers' decisions are made based on equal access to information regardless of their relationship with the PDO institution or socioeconomic traits (age, previous occupation, and education level among others). Thus, farm and market structure between PDO and non-PDO farms can be compared. In addition, farmers' perceptions of farm activities and PDO functions for both groups of farmers can be explored.

\section{MATERIAL AND METHODS}

The study was performed on the island of La Palma (Canary Islands, Spain), where traditional Queso Palmero (La Palma cheese) is produced and PDO Queso Palmero has an important market share. Queso Palmero is mainly consumed in the Canary Islands. The study was based on interviews with 68 farmers $(30$ of them participants in the PDO and 38 not) who fulfill the required conditions to access PDO labelling (such as raising the Palmera 
goat breed), and produce and sell their own cheese. These sampling conditions allow us to isolate changes in farms not produced by the effect of PDO. Moreover, over $90 \%$ of goat farms in the studied area were included in the sample. The interviews included open-ended questions sorted by importance-relevance and sense (negative or positive) and close-ended questions to determine quantitative data. The analysis of open-ended answers was based on coding, identifying different sections of responses with different emerging concepts or ideas. The coding of responses allowed us to establish the frequency of core ideas and to classify the responses related to each emerging concept (44).

We performed distance-based permutational ANOVA (PERMANOVA) to analyze the effects of PDO (PDO label - non-PDO label), type of cheese (fresh, soft, semi-cured or cured) and market channel (middlemen, supermarket or direct to consumers) as fixed effects and private brands (farmers) as nested random factors of PDO label effect on price. PERMANOVA analyzes dependent variables as a multidimensional matrix based on distance between samples, which avoids the effects of lack of normality, homoscedasticity and independency of residuals (2). When there were significant differences, pair-wise comparisons with t-statistics were applied (2). Farmers' participation in the PDO scheme was evaluated with logit models (36), where the dependent variable takes a value of 0 if farmers do not participate in the protected label scheme and value 1 if they do. Categorical explanatory variables are age (indicator of generational replacement), educational level (as measure of innovation capacity (14)), former occupation (indicator of linkage to rural sector), length of activity (indicator of linkage to goat sector), proportion of family in workforce (measure of internal resources use, level of commoditization as indicator of autonomy (41)), farm size (measure of farm structure), grazing hours (measure of linkage to land resources), sales channels and cheese types (measure of diversification of products and channels). Conditional backward method was used to establish the best model.

Correspondence analysis (CA) was used to evaluate the frequency of ideas about cheese production and PDO performance. The effect of each group of farmers (PDO (0) and non-PDO (2) farmers) on ideas about farmers' activities was evaluated using logistic regression with CA scores on the two first axes as independent variables. PERMANOVA was implemented using PRIMER 6.0 and PERMANOVA+ (PRIMER-E Ltd, Plymouth, UK). CA and logistic regression were run with SPSS statistical package (43).

\section{RESUltS}

Protected Designation of Origin Queso Palmero has protected traditional goat farmers of La Palma (Canary Islands, Spain) since 2001. The most important requirements are related to the protection of the local goat breed (other breeds are not permitted) and traditional characteristics of cheese (shape, weight, size, color, protein and fat content among others). Although dairy industries can produce PDO cheese, most of the farmers prefer to make their own cheese on their family farms. Therefore, PDO protects the current production systems, and its rules and requirements do not entail extra production costs.

The results are organized in three parts. Firstly, the effects of a common label (PDO) or private brand on cheese price are described. Secondly, goat production systems as a measure of the effect of a PDO on farm style are characterized. Finally, farm perception analysis completes the description of farm styles.

\section{PDO and price}

Farmers participating in PDO schemes received significantly higher prices than non-PDO farmers (pseudo- $F=37.72$; p level $<0.000$ ), but this premium price is more related to the type of cheese they produce, as the interaction between type and PDO label shows (pseudo- $F=20.91$; p level < 0.000) (table 1, page 200). Furthermore, the effect of a private brand (pseudo-F $=2.34$; p level $=0.002 ; \eta^{2}=0.207$ ) is stronger than the PDO label effect $\left(\eta^{2}\right.$ $=0.177$ ) on cheese price. Additionally, the overall effect of market channel, brand and type of cheese jointly explain over $60 \%$ of total variance $\left(\eta^{2}=0.615\right)$. 
Different lower-case letters represent significant differences among types of cheese and different capital letters represent significant differences between PDO and nonPDO farms ( $\mathrm{p}<0.05)$. Diferentes letras minúsculas indican diferencias significativas entre tipos de quesos y diferentes letras mayúsculas indican diferencias significativas entre quesos por etiquetado $(p<0,05)$.

Table 1. Average and standard error of prices received by farmers based on PDO and type of cheese. All types of cheese, except fresh, are included in the PDO label.

Tabla 1. Media y error estándar de los precios percibidos por los productores en relación con la pertenencia a la DOP y al tipo de queso. Todos los tipos de quesos, excepto el queso fresco, son etiquetados por la DOP.

\begin{tabular}{|l|c|c|c|}
\cline { 2 - 4 } \multicolumn{1}{c|}{} & PDO & Non-PDO & Total \\
\hline Fresh & $8.39(0.41)^{\mathrm{Aa}}$ & $7.82(0.17)^{\mathrm{Aa}}$ & $8.01(0.18)^{\mathrm{a}}$ \\
\hline Soft & $8.74(0.36)^{\mathrm{Aab}}$ & $6,71(0.36)^{\mathrm{Bb}}$ & $8.06(0.34)^{\mathrm{a}}$ \\
\hline Semi-cured & $9.70(0.45)^{\mathrm{Ab}}$ & $7.73(0.26)^{\mathrm{Ba}}$ & $8.98(0.33)^{\mathrm{b}}$ \\
\hline Cured & $13.31(0.54)^{\mathrm{Ac}}$ & $8.17(0.60)^{\mathrm{Bab}}$ & $12.34(0.68)^{\mathrm{c}}$ \\
\hline Total & $9.99(0.32)^{\mathrm{A}}$ & $7.64(0.14)^{\mathrm{B}}$ & \multicolumn{1}{|c}{} \\
\hline
\end{tabular}

Market channels also affect cheese prices (pseudo-F $=30.92$; p level $<0.000$ ). For example, farmers receive significantly lower income from middlemen (traditional channel) compared with more modern market chains (supermarket, grocery stores, hotels and direct to consumers). Therefore, shorter and more modern sales channels tend to provide higher prices for farmers. Farmers that use direct channels tend to be involved in PDO schemes more frequently in comparison with non-PDO farmers $(B=3.70$; Wald $=2.71$; $\mathrm{p}-$ level $<0.001)$, who prefer hotels, grocery stores, supermarkets and restaurants (Log likelihood = 53.13; Nagelkerke $\mathrm{R}^{2}=0.46$ ). However, a traditional middleman channel is excluded from the logit model as both (PDO and non-PDO farmers) use this channel, even though it offers lower prices.

Cheese prices also increase with curing processes, as expected, since consumers are often willing to pay more for cured cheese. However, these increases occur only in the case of cheese produced by PDO farmers, whereas non-PDO farmers are not able to get added value for more cured cheese, and they receive significantly lower prices except in the case of fresh cheese. It seems that PDO farmers produce specific products for the market, but in the case of non-PDO farmers, curing processes are probably more related to a strategy for fresh cheese surplus management rather than product diversification.

\section{Characterization and farmers' perceptions}

A Logit model based on backward method procedure establishes education level, grazing, types of cheese and market channel diversification as independent variables (Log likelihood = 46.95; Nagelkerke $\left.\mathrm{R}^{2}=0.66\right)$. Results show that PDO farmers tend to have significantly higher educational levels than non-PDO farmers $(B=2.89$; Wald $=5.81 ; \mathrm{p}-$ level $=0.016)$. They are also likely to manage goats in grazing systems $(B=4.60$; Wald $=10.62 ; \mathrm{p}-$ level $=0.001)$ and produce more than three different types of cheese $(B=3.69$; Wald $=6.32 ; \mathrm{p}$ - level $=0.012)$ that they sell to several customers through different market channels $(B=$ 1.58; Wald $=4.06$; $\mathrm{p}$ - level $=0.044$ ). Farmers' age, previous jobs, labor force structure, farm size or activity length do not characterize PDO farmers or non-PDO farmers.

Farmers' ideas and perceptions significantly affect the likelihood of their being involved in a protection structure (figure 1, page 201), as can be seen by the logit model between CA axis 1 scores and farmer group $(B=3.06$; Wald = 9.55; p level < 0.05; Log likelihood = 75.66; Nagelkerke $\mathrm{R}^{2}=0.33$ ). However, ideas related to CA axis 2 do not explain farmers' behavior regarding PDO labels $(\mathrm{B}=0.41$; Wald $=1.73$; $\mathrm{p}$ level $>0.05$; Log likelihood = 93.06; Nagelkerke $\mathrm{R}^{2}=0.04$ ). Therefore, PDO farmers often highlight that two of the most positive features of goats' cheese production is the recognition of product quality ("I like my customers' recognition"; "Customers like my cheese and they admit it"; "prizes in cheese competitions") and the fact that they are the sole owners of their farms ("I'm my own boss"; "I don't have a boss"). Therefore, they manage their farms according to their own criteria and ideas, and they control the production process ("I control my daily schedule"). Negative ideas about cheese prices and consequences to farm economy are less frequent in the PDO group. Therefore, this group of farmers is more concerned about their relationship with customers in terms of quality, since recognition is an important part of their activity, and they focus on the control of cheese production processes and quality (brands explain more than $20 \%$ of price variance). Therefore, their satisfaction and motivation are more outward dependent and a PDO structure provides a frame that enhances relations with consumers through quality. 
Only variables with 1 or 2 dimension scores above 1 were included. $\Delta$ positive ideas related to work and control of their own farms. * positive ideas related to social recognition of product. $\diamond$ negative ideas about the lack of support and strict requirements of public administration. $X$ positive ideas about pleasure to work with goat management and cheese production + negative ideas about production costs and cheese prices.

Solo las variables con puntuaciones superiores a 1 en la dimensión 1 o 2 fueron incluidas. $\Delta$ ideas positivas relacionadas con el trabajo y el control de sus propias explotaciones. $*$ ideas positivas relacionadas con el reconocimiento social del producto. $\checkmark$ ideas negativas relacionadas con la falta de apoyo y los requerimientos de la administración pública. $X$ ideas positivas sobre el placer de trabajar con ganado caprino y producir queso. + Ideas negativas sobre los costes de producción y los precios del queso.

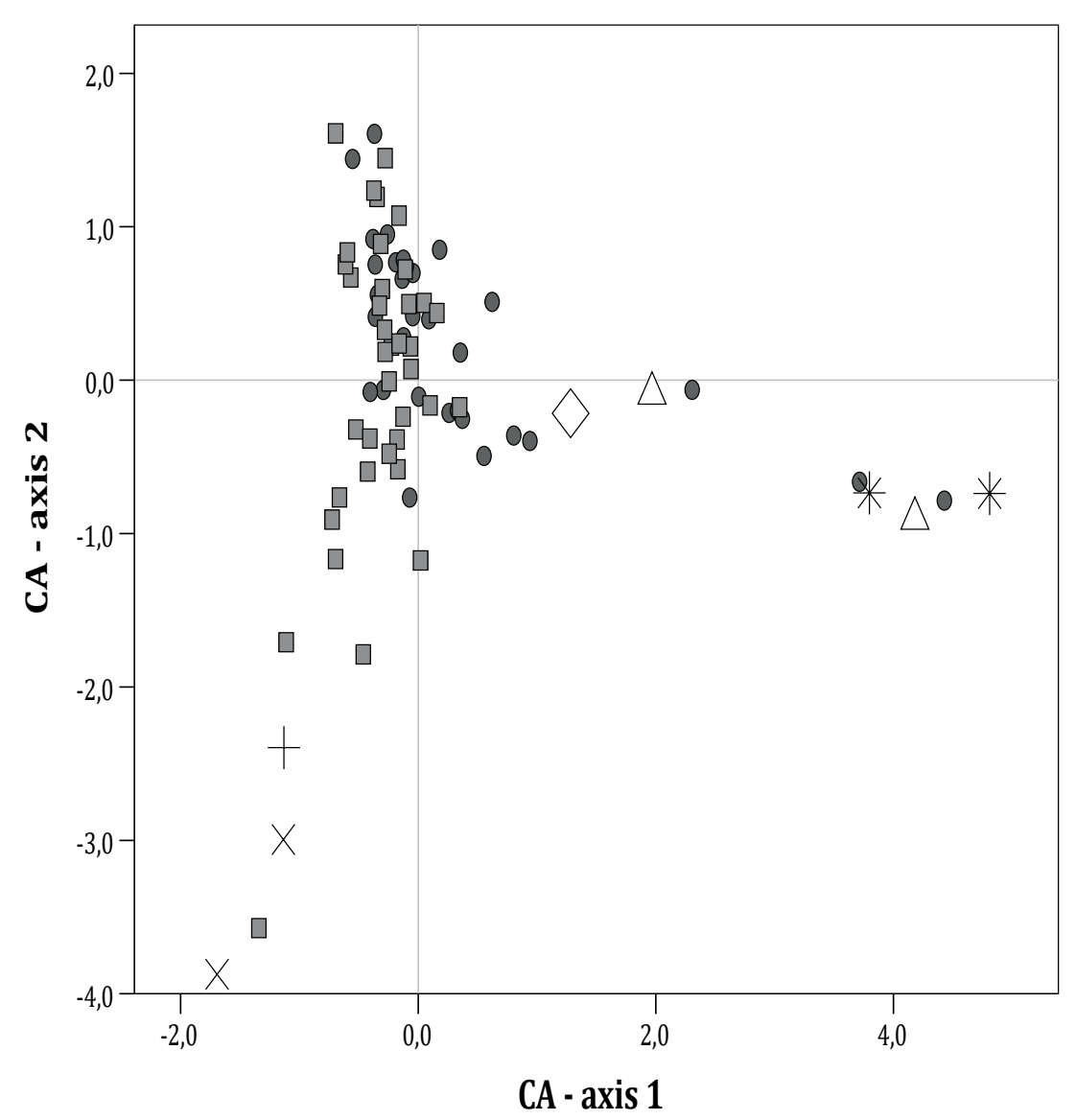

Figure 1. CA plot of PDO (•) and non-PDO (ם) farmers according to frequency of positive and negative ideas about goats' cheese production activity. Eigenvalue of axes 1 and 2 are 0.525 and 0.465 , respectively ( $16.0 \%$ the total inertia).

Figura 1. Resultados del análisis de correspondencia (CA) de los productores pertenecientes a la DOP $(\bullet)$ y no pertenecientes a la DOP $(\square)$ de acuerdo con la frecuencia de ideas positivas y negativas sobre la actividad de la producción de queso de cabra. Autovalores de los ejes 1 y 2 son 0,525 y 0,465 , respectivamente $(16,0 \%$ de la inercia total).

By contrast, non-PDO farmers tend to have positive ideas about the pleasure of goat farming and cheese production ("I like the animals and this job"; "We like goats and the job of cheese making") and negative ideas about cheese prices and production costs ("Fodder is so expensive"; "Fodder is expensive and cheese prices don't increase"). Positive ideas about recognition, about the advantages of farm ownership and the lack of administration support ("The institution's requirements are too tough"; "too much bureaucracy"; "We are the forgotten sector") are less frequent (figure 1). Non-PDO farmers' satisfaction and motivation are more related to the activity itself regardless of market and customer recognition, and therefore is inward dependent. Thus, their main concerns are more focused on the production system and its problems (costs, cheese prices and others). In this context, a PDO is not a source of potential interests for this group of farmers.

Correspondence Analysis of frequency of ideas regarding PDO organization activities shows different perceptions and views among PDO farmers $(35.6 \%$ the total inertia explained by axis 1 and 2). Low scores of some variables in CA axes 1 and 2 show a similar frequency of groups of ideas among farmers. There is a general agreement about cheese and milk quality control ("They [PDO] analyze milk and cheese"; "They control milk and cheese quality") and about the importance of Queso Palmero PDO label ("My cheese is differentiated by a quality label"; "The label certifies the cheese's quality and helps us to export it"). These results highlight quality enhancement as farmers' main motivation to join a PDO scheme. 


\section{Discussion}

Several authors have found that protected label schemes provide added value and premium prices for farmers $(10,15)$. It has also been found that cheese labels under PDO systems achieve significantly higher prices than those that do not have labels. However, the importance of brand on price formation is more relevant than protected labels as some researchers have suggested (3). Indeed, in a dual context such as the PDO Queso Palmero case (private and common labels), cheese price depends on brand reputation and common label reputation (10), both are extrinsic attributes of products that affect consumers' quality perceptions and willingness to pay for these products $(1,24,33)$. Therefore, premium prices for PDO farmers could be the result of the combined effect of private brand and common label, since the PDO or the brand itself would be not enough to achieve these premium prices. This is related to the combination of quality-geography nexus and consumers' willingness to pay for products related to 'localness and terroir' $(25,29,35)$. The PDO effect is more effective for those farmers who are also involved in building private reputations (30) mainly through differentiated quality. In the case of the PDO for Queso Palmero, private reputation is also enhanced through the production of more processed cheese (cured and semi-cured) based on local resources (grazing), which provides specific traits and identities (private and common), and through product diversification (different types of cheeses). These characteristics are more frequent in PDO farmers, who state their concerns about consumer satisfaction and acknowledge the role of the PDO in quality control and promotion, as our results have shown. Therefore, PDO structures reinforce previous private efforts for quality and reputation rather than providing an overall reputation for cheese production.

The PDO label explains less than $20 \%$ of price variability, but it provides other benefits and structural changes that encourage some farmers to adopt the protected label (15, 26). Apart from brand, price is related to two other factors. On the one hand, the type of cheese produces greater price differences than any other factor in the model but differentially affects PDO and non-PDO farmers. In the context of PDO, results show how price responds to quality, since cheese is more expensive as it cures only under the common label (PDO). On the other hand, market channel provides higher prices if the chain is shorter probably because, among other factors, consumers appreciate the contact with farmers, as some authors have found (5). It also appears that PDO systems interest farmers who like to have a closer relationship with consumers and who produce more cured cheese to achieve better prices. Both factors are related to differentiated quality and reputation and confirm the assumption of complementary roles of private brands and common labels $(11,30)$.

Results suggest that PDO and non-PDO farmers represent two different farming styles that entail different conceptions of agriculture and food production (table 2, page 203). One is a more production-oriented style (non-PDO farmers) that responds to a productivism agrarian model mainly focused on productivity and agricultural models $(17,45)$. The other is more market oriented (PDO farmers) that matches a neo-endogenous rural model, since it represents the combination of local (natural resources) and external (network and connections with other activities and initiatives) forces and contributes to local institutional capacity $(16,17,41)$. According to our results, both models coexist, though they are not stages of rural development, as the weak effect of age on type of farmers shows. However, education level does differentiate between PDO and non-PDO farmers, which suggests education is driving changes in rural perceptions toward diversification and multifunctionality.

Production-oriented farmers (non-PDO farmers) focus on productivity and cost management and, therefore they perceive that their farms depend on production and economic efficiency that is mainly related to inward structures and strategies. Probably, these farmers produce for specific consumers who are more concerned with price-quality balance and could be classified as pragmatic consumers (5). As quantity is one of their most important concerns, farms are mainly intensive with industrial structures and with management that aims to maximize productivity. However, differentiated quality is not as important, since these farmers do not implement strategies for differentiation, such as local resource usage (intensive systems) or more processed cheese production (curing highlights specific traits). Their production is more concentrated on less processed cheese as curing processes do not provide added value (but rather increase loss risks) and is probably a strategy for surplus management. Moreover, their market structure is based on traditional 
channels, such as middlemen. These factors prioritize short-term revenues and investment in quality improvement is not encouraged (30). These systems are closer to classical farming strategies such as labor-driven intensification (concern about productivity) and high-tech intensification (less importance of grazing) (38).

Table 2. Main traits of two farming styles as a result of the effect of PDO implementation.

Tabla 2. Rasgos principales de los estilos de agricultura como resultado del efecto de la implementación de la Denominación de Origen Protegido.

\begin{tabular}{|c|c|c|}
\hline Characteristic & Non-PDO & PDO \\
\hline Farm style & Production - oriented & Market - oriented \\
\hline Land use - local resources & Low & High \\
\hline Price & Medium & High \\
\hline $\begin{array}{c}\text { Production - market } \\
\text { diversification }\end{array}$ & Low & high \\
\hline Main market chain & Supermarket and groceries & Direct market and other short chains \\
\hline Drivers of decision-making & $\begin{array}{c}\text { Farm and production system } \\
\text { Inward dependent }\end{array}$ & $\begin{array}{c}\text { Consumer relationship } \\
\text { Outward dependent }\end{array}$ \\
\hline Main concerns & $\begin{array}{c}\text { Productivity } \\
\text { Quality }\end{array}$ \\
\hline Main strategies & $\begin{array}{c}\text { Classical } \\
\text { Relation with consumers }\end{array}$ \\
\hline & $\begin{array}{c}\text { New } \\
\text { High - tech intensification }\end{array}$ & $\begin{array}{c}\text { Creation of new micro - enterprises } \\
\text { Multi-functionality in agriculture }\end{array}$ \\
\hline
\end{tabular}

However, farmers in PDO schemes have a market-oriented style and are concerned about differentiated quality, since their farms are based on market relationships instead of production system efficiency. Therefore, they aim to establish a fluent and effective dialogue with consumers. This allows them to adapt production and improve quality as a path to increasing income. Production is based on grazing systems and focuses on more processed cheese as a way of providing specific traits that would entail premium prices. Furthermore, most of their production is sold direct to consumers and, therefore, their interactions with the market are more intense and productive in terms of feedback. PDO producers are more centered on quality seekers for whom certifications (common labels) are quality guarantees (5). These farms are implementing new farming strategies (38), such as creating new micro enterprises and multifunctionality in agriculture (market and product diversification) and agroecology (relevance of grazing).

Therefore, a PDO is a powerful development tool that drives changes in the livestock sector beyond just adding value (27). These changes are mainly related to reattachment with local resources, as other authors have found (40), shortening and diversification of market channels and focusing on quality instead of quantity. All these changes not only provide novel attributes for which consumers are willing to pay more for $(4,39)$ but also strengthen farms through market and production diversification that provide higher resilience against market fluctuations thanks to the intensification of networks (12). Although the effect of GIs on farm transformation have been little studied, some examples have been analyzed in the case of Roquefort cheese (40), GIs of French Alps $(20,21)$ as well as for some local breeds in Mediterranean areas (23). These authors found a significant effect of GIs on farm transformation, mainly in terms of unexpected results. Beside farm-scale transformation and benefits, PDOs can contribute to protecting and developing other resources on a wider scale, such as native breeds and local culture heritage protection (26).

PDO assessment based on supply chain strategy or of extended territorial strategy (increasing employment and revenues within supply chain, and/or local economy) (47) could be complemented by measurements related to intensity of local resource use (grazing and local forage) or to endogenous or neo-endogenous models and increasing local relationships as resilience drivers (12). Although these are key elements of current models of development in Europe $(34,45)$, our results suggest there is a coexistence of two different farming strategies in the same geographical and socio-economic context. Indeed, they are 
not stages of linear evolution but rather two paths of development, therefore they must not be approached in terms of backward or advanced systems. Both require different supporting strategies that are hidden behind aggregated statistics based on common variables (38).

\section{Conclusions}

PDO schemes work as change drivers for farms that go beyond adding value through premium prices and increasing income. Indeed, the PDO effect entails radical change in farms and farmers involving coupling (or recoupling) with local resources and establishing new relationships and networks, among others. However, it should be noted that PDO schemes do not create production systems in terms of substitution of classical ones, what it does is create novel spaces of development that coexist with other farm styles. Therefore, our analysis suggests that rural development initiatives such as PDOs and other GIs would function as socio-economic spaces of creation and entrepreneurship in a horizontal relationship with others. These would entail that production models could be approached like a patchwork of different farm styles (horizontal) instead of different stages of evolution (vertical).

\section{REFERENCES}

1. Adasme-Berríos, C.; Sánchez, M.; Mora, M.; Schnettler, B.; Lobos, G.; Díaz, J. 2019. The gender role on moderator effect of food safety label between perceived quality and risk on fresh vegetables. Revista de la Facultad de Ciencias Agrarias. Universidad Nacional de Cuyo. Mendoza. Argentina. 51(1): 93-109.

2. Anderson, M. J.; Gorley, R. N.; Clarke, K. R. 2008. PERMANOVA+ for PRIMER: Guide to software and statistical methods. Plymouth. UK. PRIMER-E Ltd. $254 \mathrm{p}$.

3. Aprile, M. C.; Caputo, V.; Nayga Jr, R. M. 2012. Consumers' valuation of food quality labels: the case of the European geographic indication and organic farming labels. In International Journal of Consumer Studies. 36: 158-165. https://doi.org/10.1111/j.1470-6431.2011.01092.x

4. Balogh, P.; Békési, D.; Gorton, M.; Popp, J.; Lengyel, P. 2016. Consumer willingness to pay for traditional food products. In Food Policy. 61: 176-184. https://doi.org/10.1016/j. foodpol.2016.03.005

5. Boncinelli, F.; Contini, C.; Romano, C.; Scozzafava, G.; Casini, L. 2017. Territory, environment and healthiness in traditional food choices: insights into consumer heterogeneity. In International Food and Agribusiness Management Review. 20: 143-157. https://doi. org/10.22434/IFAMR2015.0177

6. Bonnet, C. 2001. Assessing consumer response to Protected Designation of Origin labelling: a mixed multinomial logit approach. In European Review of Agriculture Economics. 28: 433-449. https://doi.org/10.1093/erae/28.4.433

7. Bouamra-Mechemache, Z.; Chaaban, J. 2010. Determinants of adoption of protected designation of origin label: evidence from the French brie cheese industry. In Journal of Agricultural Economics. 61: 225-239. https://doi.org/10.1111/j.1477-9552.2009.00234.

8. Callois, J. M. 2006. Quality labels and rural development: a new economic geography approach. In Cahiers d'Economie et Sociologie Rurales. 78: 32-51.

9. Cei, L.; Stefani, G.; Defrancesco, E.; Lombardi, G. V. 2018. Geographical indications: A first assessment of the impact on rural development in Italian NUTS3 regions. In Land Use Policy. 75: 620630. https://doi.org/10.1016/j.landusepol.2018.01.023

10. Chever, T.; Renault, C.; Renault, S.; Romieu, V. 2012. Value of production of agricultural products and foodstuffs, wines, aromatised wines and spirits protected by a geographical indication (GI). Final report to the European Commission, TENDER N ${ }^{\circ}$ AGRI-2011-EVAL-04. Brussels. 85 p.

11. Costanigro, M.; Bond, C. A.; McCluskey, J. J. 2012. Reputation leaders, quality laggards: incentive structure in markets with both private and collective reputations. In Journal of Agricultural Economics. 63: 245-264. https://doi.org/10.1111/j.1477-9552.2011.00331.x

12. Darnhofer, I.; Lamine, C.; Strauss, A.; Navarrete, M. 2016. The resilience of family farms: Towards a relational approach. In Journal of Rural Studies. 44: 111-122. https://doi.org/10.1016/j. jrurstud.2016.01.013

13. Deselnicu, O. C.; Costanigro, M.; Souza-Monteiro, D. M.; Mcfadden, D. T. 2013. A meta-analysis of geographical indication food valuation studies: what drives the premium for origin based labels? In Journal of Agricultural and Resource Economics. 38: 204-2019. https:// doi.org/10.22004/ag.econ.158285 
14. Feder, G.; Savastano, S. 2017. Modern agricultural technology adoption in sub-saharan Africa: A four-country analysis. In: Pingali P, Feder G (eds) Agriculture and Rural Development in a Globalizing World: Challenges and Opportunities. New York. Routledge Earthscan. 11-25.

15. Giraud, G. 2016. Economics of goat and ewe milk cheeses with protected designation of origin in Europe. In: Deiters J, Rickert U, Schiefer G (eds) $10^{\text {th }}$ International European Forum on System Dynamics and Innovation in Food Networks. Innsbruck, Austria. International Center for Management. 381-383.

16. Hajdukiewicz, A. 2014. European Union agri-food quality schemes for the protection and promotion of geographical indications and traditional specialities: an economic perspective. In Folia Horticulturae. 26: 3-17. https://doi.org/10.2478/fhort-2014-0001

17. Hubbard, C.; Gorton, M. 2011. Placing agriculture within rural development: evidence from EU case studies. In Environment and Planning C: Government and Policy. 29: 80-95. https://doi. org/10.1068/c1031r

18. Huber, R.; Bakker, M.; Balmann, A. 2018. Representation of decision-making in European agricultural agent-based models. In Agricultural Systems. 167: 143-160. https://doi. org/10.1016/j.agsy.2018.09.007

19. Kosanic, A.; Petzold, J.2020. A systematic review of cultural ecosystem services and human wellbeing. In Ecosystem Services. 45: 101-168. https://doi.org/10.1016/j.ecoser.2020.101168

20. Lamarque, P.; Lambin, E. F. 2015. The effectiveness of marked-based instruments to foster the conservation of extensive land use: The case of Geographical Indications in the French Alps. In Land Use Policy. 42: 706-717. https://doi.org/10.1016/j.landusepol.2014.10.009

21. Lambert-Derkimba, A.; Minéry, S.; Barbat, A.; Casabianca, F.; Verrier, E. 2010. Consequences of the inscription of local breeds in protected designation of origin cow cheese specifications for the genetic management of the herds. In animal. 4: 1976-1986. https://doi.org/10.1017/ S1751731110001333

22. Lambert-Derkimba, A.; Lauvie, A.; Verrier, E. 2013. How the development of products valorizing local breeds changes breeding goals: examples from French cattle breeds. In Animal Genetic Resources/Ressources génétiques animales/Recursos genéticos animales. 53: 135-140. https://doi.org/10.1017/s2078633612000768

23. Lauvie, A.; Hadjipavlou, G.; Araba, A.; Casabianca, F.; Ligda, C. 2016. The interactions between product valorisation and genetic management: Applying a common framework to analyze four cases of sheep and goat local breeds in the Mediterranean area. In Options Méditerranéennes, A. 181-185.

24. Lee, D.; Moon, J.; Ryu, M. H. 2019. The effects of extrinsic cues on online sales of fresh produce: a focus on geographical indications. In Cahiers Agriculture. 28: 1-7.

25. Loureiro, M. L.; Umberger, W. J. 2003. Estimating Consumer Willingness to Pay for Country-of-Origin Labeling. In Journal of Agricultural and Resource Economics. 28: 287-301. https://doi. org/10.22004/ag.econ.31091

26. Macías Vázquez, A.; Alonso González, P. 2015. Managing collective symbolic capital through agrofood labelling: Strategies of local communities facing neoliberalism in Spain. In Journal of Rural Studies. 41: 142-152. https://doi.org/10.1016/J.JRURSTUD.2015.08.003

27. Marescotti, A. 2003. Typical products and rural development: who benefits from PDO/PGI recognition? In Food Quality Products in the Advent of the $21^{\text {st }}$ Century: Production, Demand and Public Policy 83ème Séminaire de l'EAAE, Chania, Grèce. 4-7.

28. Marsoner, T.; Egarter Vigl, L.; Manck, F.; Jaritz, G.; Tappeiner, U.; Tasser, E. 2018. Indigenous livestock breeds as indicators for cultural ecosystem services: A spatial analysis within the Alpine Space. In Ecological Indicators. 94: 55-63. https://doi.org/10.1016/j.ecolind.2017.06.046

29. McCaffrey, S. J.; Kurland, N. B. 2015. Does "Local" Mean Ethical? The U.S. "Buy Local" Movement and CSR in SMEs. In Organization \& Environment. 28: 286-306. https://doi. org/10.1177/1086026615586795

30. Menapace, L.; Moschini, G. 2012. Quality certification by geographical indications, trademarks and firm reputation. In European Review of Agricultural Economics. 39: 539-566. https://doi. org/https://doi.org/10.1093/erae/jbr053

31. Millet, M.; Casabianca, F. 2019. Sharing values for changing practices, a lever for sustainable transformation? The Case of farmers and processors in interaction within localized cheese sectors. In Sustainability. 11: 4520. https://doi.org/10.3390/su11174520

32. Ministerio de Agricultura Pesca y Alimentación. 2018. Datos de las Denominaciones de Origen Protegidas (D.O.P.), Indicaciones Geográficas Protegidas (I.G.P.) y Especialidades Tradicionales Garantizadas (E.T.G.) de Productos Agroalimentarios. Madrid. Spain.

33. Miyazaki, A. D.; Grewal, D.; Goodstein, R. C. 2005. The effect of multiple extrinsic cues on quality perceptions: A matter of consistency. In Journal of Consumer Research. 32: 146-153. https://doi.org/10.1086/429606

34. Naldi, L.; Nilsson, P.; Westlund, H.; Wixe, S. 2015. What is smart rural development? In Journal of Rural Studies. 40: 90-101. https://doi.org/10.1016/j.jrurstud.2015.06.006

35. Onozaka, Y.; Nurse, G.; McFadden, D. T. 2010. Local food consumers: How motivations and perceptions traslate to buying behavior. In The magazine of Food, Farma and Resources Issues. 25: 1-6. 
36. Peng, C. Y. J.; Lee, K. L.; Ingersoll, G. M. 2002. An Introduction to Logistic Regression Analysis and Reporting. In The Journal of Educational Research. 96: 3-14. https://doi. org/10.1080/00220670209598786

37. Peschel, A. O.; Grebitus, C.; Steiner, B.; Veeman, M. 2016. How does consumer knowledge affect environmentally sustainable choices? Evidence from a cross-country latent class analysis of food labels. In Appetite. 106: 78-91. https://doi.org/10.1016/j.appet.2016.02.162

38. Ploeg, J. D. van der; Ventura, F.; Milone, P. 2016. Research for agri committe - farm structural change in western Europe and the CAP. In: Research for agri committe - structural change in EU farming: How ca the CAP support a $21^{\text {st }}$ century European modelo of agriculture? Brussels. European Union. 7-77.

39. Printezis, I.; Grebitus, C. 2018. Marketing channels for local food. In ecological economics. 152: 161-171. https://doi.org/10.1016/j.ecolecon.2018.05.021

40. Quetier, F.; Marty, P.; Lepart, J. 2005. Farmers' management strategies and land use in an agropastoral landscape: roquefort cheese production rules as a driver of change. In Agricultural Systems. 84: 171-193. https://doi.org/10.1016/j.agsy.2004.05.005

41. Ramírez-Gómez, C. J.; Robledo Velasquez, J.; Aguilar-Avila, J. 2020. Trust networks and innovation dynamics of small farmers in Colombia: An approach from territorial system of agricultural innovation. Revista de la Facultad de Ciencias Agrarias. Universidad Nacional de Cuyo. Mendoza. Argentina. 52(2): 253-266.

42. Schneider, S.; Niederle, P. A. 2010. Resistance strategies and diversification of rural livelihoods: the construction of autonomy among Brazilian family farmers. In The Journal of Peasant Studies. 37: 379-405. https://doi.org/10.1080/03066151003595168

43. SPSS 1986. SPSS/PC+ V.6.0. Base Manual. Chicago. SPSS Inc.

44. Stemler, S. 2001. An overview of content analysis. In practical assessment, research \& evaluation. 7:1-10.

45. Terluin, I. J. 2003. Differences in economic development in rural regions of advanced countries: an overview and critical analysis of theories. In Journal of Rural Studies. 19: 327-344. https://doi.org/10.1016/S0743-0167(02)00071-2

46. The European Parliament and the Council of the European Union. 2012. Regulation (EU) No. 1151/2012 of the European Parliament and of the Council of 21 November 2012 on quality schemes for agricultural products and foodstuffs. Brussels. Official Journal of the European Union. 29 p.

47. Tregear, A.; Arfini, F.; Belletti, G.; Marescotti, A. 2007. Regional foods and rural development: The role of product qualification. In Journal of Rural Studies. 23: 12-22. https://doi. org/10.1016/j.jrurstud.2006.09.010

48. Unnevehr, L.; Eales, J.; Jensen, H.; Lusk, J.; McCluskey, J.; Kinsey, J. 2010. Food and Consumer Economics. In American Journal of Agricultural Economics. 92: 506-521. https://doi. org/10.1093/ajae/aaq007

49. Zander, K. K.; Signorello, G.; De Salvo, M.; Gandini, G.; Drucker, A. G. 2013. Assessing the total economic value of threatened livestock breeds in Italy: Implications for conservation policy. In Ecological Economics. 93: 219-229. https://doi.org/10.1016/j.ecolecon.2013.06.002 